\title{
IBRAHIM HUSEN FIQIH INDONESIA
}

Oleh : Ridwan Jamal

\begin{abstract}
ABSTRAK
Ibrahim Husen sesosok ulama terkemuka Indonesia yang mendapat tempat terhormat di ruang hati umat Islam Indonesia, teristimewa kalangan terpelajar Islam. Ia seorang Profesor fiqih yang cukup raj in dan cerdas mere spons fenomena kefiqihan di Indonesia. Dari dirinya (melalui keduduk-annya sebagai Ketua Komisi Fatwa MUI Pusat pada masa kepemimpinan K. H. Hasan Basri) lahir banyak fatwa kefiqihan.

Ibrahim Husen sangat concern terhadap pengassimilasian antara hukum nasional dengan hukum syar'i. Menurut Ibrahim Husen, hukum nasional Produk pemerintah berupa peraturan perudang-undangan yang tidak bertentangan atau sejiwa dengan hukum syar'i dapat dinilai sebagai hukum Islam.

Tulisan ini akan melacak pokok pikiran Ibrahim Husen tentang upaya pendinamisasian hukum Islam agar selalu dapat berfungsi sebagai pedoman hidup bagi umat Islam dalam segala tempat dan masa ke depan.
\end{abstract}

\section{PENDAHULUAN}

Kita ketahui bersama bahwa setelah keruntuhan kekuasaan politik Islam, kemajuan ilmu dan pengetahuan Islam pun ikut terpuruk, bahkan kemunduran ilmu itu terlihat jauh-jauh sebelum kekuasaan politik Islam jatuh.

Keruntuhan kekuasaan Islam didahului oleh huru-hara sosial politk yang menimbulkan ketidakstabilan. Dalam kondisi seperti itu adalah sulit bagi umat melakukan kajian dan penelitian secara mendalam, apalagi menghasilkan karyakarya monumental yang mengikuti per kembangan dan tuntutan zaman.

Sebagai konsekuensinya, kajian setelah itu tidak orisinil lagi sebab yang berkembang adalah pengulangan-pengulangan terhadap karya-karya terdahulu dalam bentuk penjelasan (syarh) dan hasyiah (penjelasan atas penjelasan) dalam kajian-kajian keilmuan, khususnya ilmu-ilmu yang terkait dengan sumbersumber ke-Islaman. sumber ke-Islaman.

Lama kelamaan, tulisan-tulisan yang ada semakin abstrak dan nyaris tidak ada relevansinya dengan problematika umat. Para fuqaha terlibat dalam per- 
debatan-perdebatan "kosong" yang penuh sesak dengan terma-terma logika deduktif tekstual, bukan induktif-kontekstual.

Akibatnya, kajian hukum Islam semakin jauh dari persoalan real umat karena hampir-hampir tidak memiliki korelasi dengan apa yang mereka rasakan. Umat dari satu sisi ingin mengimplementasikan hukum agamanya, tapi di sisi lain formulasi hukum itu sangat tidak relevan dengan kondisi mereka.

Ibrahim Hosen adalah seorang tokoh yang menyadari penderitaan umat, khususnya umat muslim Indonesia. Dia ingin membangun kembali tradisi pemikiran hukum yang pernah ada di zaman kejayaan ilmu ini. Dia menyadari bahwa rahasia kebesaran fiqih di masa kejayaannya adalah sebab orang-orang yang membawanya adalah mereka yang mampu mendialogkan antara wahyu transendental yang sifatnya mutlak dan sudah berakhir dengan konteks masyarakat waktu itu. Ini tercermin dari ucapannya bahwa norma dan nash agama terbatas, dan kesemuanya itu harus mendapat ketetapan hukum. ${ }^{1}$

Dalam kesempatan ini kita akan melihat ide-ide pokok Ibrahim Hosen dalam rangka membangun fiqih Islam secara umum dan fiqih Indonesia secara khusus.

\section{BIOGRAFI IBRAHIM HUSAIN}

Tokoh kita ini lahir pada tanggal 1 Januari 1917 di Bengkulu dari sebuah keluarga alim ulama keturunan Bugis-Makassar. Dia mulai mengecap pendidikan di Madrasah Assagaf setingkat Ibti-daiyah di Singapura hingga kelas IV. Kemudian dia pindah ke Madrasah Khair Arabiche School setingkat SD di Lampung pada tahun 1932. setelah itu dia melanjutkan studinya ke Darul Muallimin setingkat SMP di Jakarta tahun 1935, lalu Pesantren Gunung Puyuh, Sukabumi.2

Setelah menyelesaikan tingkat Aliyahnya, dia melakukan pengem-baraan ilmiah dari kyai ke kyai. Pada tahun 1938, dia belajar pada KH. Abdul Latif di Pesantren Cibeber, Cilegon, Banten; bela-jar dan mengajar di Jami'at Khair Tanah Abang Jakarta; lalu belajar Alquran, ilmu qiraat dan tilawah serta ilmuilmu Islam pada KH. Shaleh Makmum di Pesantren Lontar, Serang, Banten; KH. Abbas di Pesantren Buntet, Cirebon; KH. Ahmad Assagaf di Pesantren Solo;

KH. Sanusi di Pesantren Gunung Puyuh; Sekolah Jepang Gunsei Gakko untuk 
pendidikan pegawai pada tahun 1943 dan pendidikan formalnya yang terakhir Fakultas Syariah, Universitas Al-Azhar yang diselesaikannya pada tahun $1960 .^{3}$

Dia juga pernah beberapa jabatan penting diantaranya Dekan (19621964) dan Rektor (1964-1966) Fakultas Syariah IAIN Raden Fatah Palembang; pendiri dan Rektor Institut PTIQ dan HQ Jakarta (1971-1977); staf ahli Menag. RI (1971 1982); ketua komisi fatwa MUI tahun 1980; anggota DPA RI tahun 1994. Dia juga pernah memimpin delegasi Indonesia untuk OKI di Kairo dan Islamabad tahun 1969.4

Tokoh kita ini tutup usia pada tanggal 9 Nopember 2001 di Jakarta.

\section{HUKUM ISLAM ANTARA SYARI'AH DAN FIQIH}

Berbicara mengenai hukum Islam, Ibrahim Hosen mendasarkan ide-idenya atas asumsi dasar berikut.

a. Sumber hukum bersumber dari wahyu yang diturunkan kepada Nabi Muhammad Saw.

b. Wahyu tersebut ada yang diterima Nabi melalui malaikat Jibril. Kumpulan wahyu ini dinamakan Alquran. Di samping Alquran ada yang diterima Nabi saw, secara langsung dirnana Allah swt memberikan 'pengertian' ke dalam hati dan disampaikan Nabi melalui ucapan atau perbuatan. Wahyu model kedua ini dikenal dengan Sunnah Nabi. Baik Alquran maupun sunnah, masing-masing tertuang dalam bahasa Arab dengan gaya bahasa, struktur kata dan nilai sastra yang sangat tinggi.

c. Nash Alquran dan Sunnah yang arti- nya jelas, tegas dan tidak mengandung penafsiran atau pentakwilan, akan tetapi dari segi penerimaan oleh para sahabat tidak terjadi perbedaan pendapat, maka hal semacam ini dikenal dengan qath'iy dari segi ma 'ulama al- din bi al-dharurah atau pna'alaih, dan tidak qath'iy dari segi dalalah lafzhiyyah.

d. Apabila redaksi ayat Alquran atau Sunnah tersebut tidak menunjukkan arti satu, maka yang demikian itu dikenal dengan zhanniyyah al-dalalah.

e. Hukum Islam yang ditetapkan oleh nash Alquran dan Sunnah yang qath'iy al-dalalah/ma'ulima min al-din bi al-dharurah atau mujma'alaih dalam istilah Ushul Fiqih dikenal dengan Syari'ah, sedangkan hukum Islam yang dilahirkan dari dalil Alquran dan Sunnah yang kata-kata atau 
redaksinya berstatus zhanniyyah al-dalalah karena mengandung penafsiran atau pentakwilan, demikian pula hukum Islam yang diperoleh melalui ijtihad bi al-ra'yi, kesemuanya itu dalam Ushul Fiqih dikenal dengan istilah fiqih. Ia bersifat zhanniy karena ia me-rupakan hasil ijtihad seorang muj tahid.

f. Berdasarkan point kelima dapat diket-ahui bahwa hukum Islam kategori Syari'ah atau yang berstatus qath'iy jumlahnya relatif kecil dibandingkan dengan hukum Islam kategori Fiqih. Sebab wahyu telah terputus dengan wafatnya Rasulullah, sementara itu persoalan baru terus bermunculan dan hak ini harus dijawab dengan ijtihad. Dengan demikian, lapangan operasional ijtihad sangatlah luas. Contoh Syariah, misalnya kewajiban mem-baca dua kalimah syahadat, shalat. Puasa ramadhan, zakat, ibadah haji, keharaman makan bangkai dan darah, durhaka kepada kedua orang tua, mencuri, sumpah palsu, dan lain sebagainya. Contoh Fiqih, seperti hal-hal yang berkenaan dengan teknis dan pelaksanaan ibadah-ibadah wajib di atas, batas-batas menutup aurat, masalah asuransi, bilangan rakaat shalat tarawih dan sebagainya.

g. Perbedaan antara Syari'ah dengan Fiqih terletak pada status dan penerapannya. Syari'ah berstatus qath'iy, artinya kebenarannya hersifat mutlak, tidak dapat ditambah dan dikurangi dan padanya tidak ada berlaku ijtihad. Dari segi penerapan, kondisi dan situasi harus tunduk kepadanya; ia berlaku untuk segenap manusia (mukallaf) di semua tempat di sepanjang tahun serta dalam segala kondisi dan situasi, penerapannya. Syari'ah berstatus qath'iy, artinya kebenarannya hersifat mutlak, tidak dapat ditambah dan dikurangi dan padanya tidak ada berlaku ijtihad. Dari segi penerapan, kondisi dan situasi harus tunduk kepadanya; ia berlaku untuk segenap manusia (mukallaf) di semua tempat di sepanjang tahun serta dalam segala ijtihad memainkan peran.

h. Lapangan ijtihad adalah dalil-dalil zhanniy yang menghasilkan hokum Islam kategori Fiqih.'

Itulah dasar-dasar pemikiran Ibrahim Hosen dalam mengembang-kan pemahaman terhadap hukum Islam. Yang menarik dari uraian ini adalah pembedaan antara Syari'ah dan Fiqih sebab ada jugs ulama yang tidak mau 
memisahkan dan membedakan antara keduanya. Memisahkan antara keduanya berarti menghilangkan kedua-duanya. Kami melihat bahwa Ibrahim Hosen tidak menerima kekhawatiran seperti itu. Dan secara singkat konsepnya tentang hubungan Syari'ah dan Fiqih adalah "hukum Fiqih adalah hukum Syari'ah tetapi hukum Syari'ah belum tentu hukum Fiqih."6

Pembedaan ini tentu saja secara metodologis dan fungsi sangat besar artinya bagi kesuksesan proyek pembaharuan yang diinginkannya dalam tradisi hukum Islam di Indonesia. Dengan menyatukan antara Fiqih dan Syari'ah tentu saja akan menutup pintu ijtihad atau setidak-tidaknya membuat kita sulit mengidentifikasi lahan ijtihad itu.

\section{BEBERAPA PRINSIP PENTING DALAM PENGEMBANGAN FIQIH}

Ibrahim Hosen menyebutkan setidak-tidaknya tujuh prinsip yang harus diperhatikan dalam rangka kelancaran pengembangan dan efektivitas Fiqih, khususnya di Indonesia.

\section{A. Kebenaran nisbi}

Sebagai hasil ijtihad kebenaran Fiqih adalah nisbi, telatif sebab ia hanya merupakan zhann dari usaha maksimal seorang mujtahid dalam upaya menggali hukum Allah yang terpendam dalam dalil. Karena itulah status Fiqih adalah zhanny, artinya ia benar tetapi mengandung ke- mungkinan salah atau salah namun mengandung kemungkinan benar. Hanya saja menurut si Mujtahid yang dominan adalah sisi kebenarannya. Kenisbian Fiqih ini telah diisyaratkan oleh Nabi dalam sebuah hadis yang berbunyi, "Apabila seorang hakim akan memutuskan perkara lalu ia berijtihad, tapi ijtihadnya salah, maka ia mendapatkan satu pahala (pahala ijtihadnya)." H. R. Bukhari dan Muslim'

Hadis ini menurut Ibrahim Hosen tidak hanya menunjukkan bahwa ijtihad yang salah pun mendapat pahala, tapi juga memberi-kan indikasi bahwa tidak semua hukum yang diperoleh melalui ijtihad itu benar. Oleh karena itu, tidak heran jika ada hasil ijtihad yang dianggap benar oleh seorang mujtahid, lalu dilemahkan oleh mujtahid lain.

Kenyataan sejarah menunjukkan para mujtahid memiliki komitmen

murni terhadap bimbingan Rasulullah dalam hadis tersebut. Itu dibuktikan 
dengan timbulnya ucapan mereka yang sangat popular, "Pendapat kami benar namun mengandung kemungkinan salah, dan pendapat selain kami salah tapi mengandung kemungkinan benar.

Bahkan menurut Ibrahim Hosen yang qath'iy al-dalalah pun ada kemungkinan untuk difiqihkan seperti hukum bagi pencuri, penzina dapat diampuni jika ia bertaubat; wanita haid saat melakukan ibadah haji boleh thawaf dengan pertimbangan zaman sekarang tidak sama dengan zaman Nabi saw. ${ }^{9}$

\section{B. Wataknya berbeda}

Fiqih sebagai hasil ijtihad dipengaruhi oleh kadar ilmu, Tatar belakang budaya dan pemikiran serta situasi dan kondisi yang melingkupi pelakunya. Sejalan dengan hal itu, sangat wajar apabila Fiqih di suatu tempat dengan tempat yang lain berbeda sejalan dengan perkemb an gan zaman yang diwarnai dengan kemajun ilmu dan teknologi pada kondisi dan situasi yang berlainan. Sehingga wring satu masalah yang diangkat kepermukaan lalu mendapat berbagai macam tanggapan yang berbeda satu sama lain.

Berangkat dari kenyataan seperti itu, sangatlah berharga apabila kita menghadapi perbedaan pendapat yang ada secara terbuka, tidak alergi terhadap salah satu pendapat. Hal seperti ini telah disinyalir dalam sebuah hadis Nabi yang aa rtinya, "Perbedaan pendapat di kalangan umatku (ulama) adalah rahmat."10

Masyarakat muslim sekarang tersebar di banyak wilayah. Setiap wilayah memiliki kondisi dan situasi real yang berbeda satu sama lain dalam banyak hal. Baahhkkaann dipertajam lagi dengan kemuncu Tan berbagai masalah yang telah melam $_{\mathrm{p}}$ aui Batas-Batas Fiqih tradisional. ${ }^{\mathrm{I}}$

Menurut Ibrahim Hosen, dinamika fiqih progresif terbuka seperti itulah yang memperkaya khazahah pemikiran Fiqih12 dan kami yakin bahwa hanya dengan itu pulalah kita dapat membangun Fiqih yang dapat dibanggakan di masa mendatang.

\section{Elastic dan Dinarnis}

Ibrahim Hosen mengharapkan kajian dan penerapan Fiqih tidak kaku dan tertutup sebab itu bukan karakter kajian Fiqih. ${ }^{13}$ Menurutnya, penerapan-nya harus memiliki keselarasan dengan tuntutan kemaslahatan manusia sesuai dengan tuntutan zaman. Ini diuraikan-nya dengan mengangkat suatu kaidah Fiqih bahwa sifat suatu fatwa itu berubah-ubah sesuai dengan peruba-han kondisi dan situasi dan hukum itu bergerak sesuai dengan illat-nya. 
Ibrahim Hosen meyakini bahwa hanya dengan cara ini hukum Islam dapat selalu relevan dengan zaman dan kemaslahatan umat.

\section{Tidak mengikat}

Prinsip ketiga tersebut hanya dapat diwujudkan apabila kita tidak terikat dengan Fiqih salah satu mazhab. Fiqih sebagai hasil ijtihad memang tidak harus mengikat selain bagi orang yang meng- ijtihadkannya sebab ia lahir dalam lingkup pengaruh ilmu, kondisi dan situasi. Konsekuensinya, Fiqih yang pernah di- anggap relevan dengan suatu zaman belum tentu cocok dengan zaman sesudah itu. Itulah hikmahnya sehingga para mujtahid melarang kita menjadi muqallid mereka dengan maksud supaya kita juga berijtihad seperti mereka sesuai dengan kondisi zaman kita.

Dalam masalah ini, Ibrahim Hosen mengemukakan kritikannya kepada sikap ilmiah para ulama muta 'akhkhirin yang mewajibkan kaum muslimin mengikuti mazhab tertentu. Bahkan yang tidak mengikuti mazhab tertentu kena sanksi. Menurutnya ini sangat bertentangan dengan firman Allah yang artinya, maka bertanyalah kepada orang- orang yang mempunyai pengetahuan jika kamu tidakmengetahui. (Q. S. Al-Nahl 43$)^{16}$

\section{E. Harus Menjadi rahmat}

Ibrahim Hosen menegaskan bahwa perbedaan di bidang Fiqih bukan saja dibenarkan oleh Islam, tapi ia juga diakui sebagai rahmat bagi umat. Jadi dengan adanya pendapat yang beragam itu, umat menjadi mudah dan longgar sebab mereka bisa memilih mazhab atau pendapat yang lebih relevan dan cocok dengan keadaan tempat dan waktu di mana berada. ${ }^{17}$

\section{F. Mengutarnakan kemaslahatan}

Tujuan agama diturunkan adalah untuk kemaslahatan manusia. Karena itu, tema utama tujuan umum dari eksistensi syari ' at Islam digambar-kan dengan, "mendatangkan kemas-lahatan dan menolak kerusakan.

\section{G. Calvin-tangan pemerintah}

Vasil ijtihad Fiqih dari seorang mujtahid atau sekelompok mujtahid sifatnya tidak mengikat karena itu untuk mewujudkan pelaksanaan Fiqih dibutuhkan campur tangan pemerintah supaya hukum Fiqih itu menjadi efektif bagi masyarakat. Hal ini juga dapat menghindarkan umat dari perpecahan yang timbul dari perbedaan pendapat ijtihad. 
Prinsip-prinsip di atas diharap-kan dapat mewuj udkan eksistensi hukum Islam di Indonesia.

\section{IJMA JAMA'I MENUJU FIQIH INDONESIA}

Ibrahim Hosen melihat bahwa umat Islam Indonesia dalam meng-hadapi berbagai tantangan zaman sejalan dengan perubahan kondisi dan waktu dituntut untuk melakukan reaktulisasi ajaran agama, khususnya hukum Islam. Untuk melakukan itu tentu saja tidak ada jalan lain kecuali melakukan ijtihad, baik secara individual maupun secara kolektif oleh orang-orang yang memiliki kemampu-an dalam disiplin ilmu yang berkaitan dengan masalah-masalah hukum Islam yang membutuhkan solusi.

Meskipun Ibrahim Hosen mengharapkan adanya ijtihad individu, tapi nampaknya karena besar dan ketatnya persyaratan menjadi seorang mujtahid, apalagi dengan kompleksitas zaman yang ada, maka is lebih cenderung jika ijtihad itu dilakukan secara kolektif sehingga pelaksana ijtihad dapat saling melengkapi satu sama lain.

Diilhami oleh hasil muktamar Lembaga Penelitin Islam Universitas AlAzhar, Ibrahim Hosen melontarkan be-berapa point yang harus diper-hatikan ; (a) Dalam menghadapi masalah-masalah baru yang dihadapi umat hendaklah kita mampu me-nyelesaikannya melalui ijtihad dengan menjadikan Alquran dan Sunnah sebagai sumber pokok. (b) Ijtihad harus dilakukan pada tempatnya, artinya selain pelakunya memenuhi kualifikasi mujtahid, ijtihad hendaknya dilakukan pada dalil-dalil zhanniy. Ijtihad tidak dapat dilakukan pada dalil-dalil (nash) yang berstatus qath'iy. (c) Bila hukum itu telah dibahas oleh imam-imam mujtahid dan ulama terdahulu maka tugas kita hanyalah melakukan ijtihad tarjih untuk memilih dan menentukan pendapat mana yang paling sesuai dengan kemaslahatan. (d) Apabila hukum masalah itu belum pernah disinggung oleh Alquran dan Sunnah serta belum pula dibahas oleh imam-imam terdahulu, maka kita harus menyelesaikannya melalui ijtihad jama'i selaku mujtahid muntasib dengan menjadikan Alquran dan Sunnah sebagai dalil pokok. Dan jika tidak memungkinkan, maka haruslah ditempuh melalui ijtihad jama'I selaku mejtahid mutlaq. ${ }^{2 !}$

Disamping itu, Ibrahim Hosen menambahkan bahwa perlu juga diingat bahwa majelis yang melakukan ijtihad jama'i harus terdiri dari para ahli dalam 
bidang-bidang ilmu yang terkait dengan masalah-masalah yang menjadi obyek ijtihad."

Sehingga keputusan hukum yang timbul dari ijtihad jama'i ini tidak seperti aturan dan perundang-undangan yang dikeluarkan DPR atau MPR misalnya sebab orang-orang yang duduk dalam kedua lembaga itu tidak perlu memenuhi syarat mujtahid dan keputusan-keputusan yang berasal dari kedua lembaga itu sifatnya meng-ikat.23

Selanjutnya, produk ijtihad jama'i dari majelis itu tidak dapat dikatakan sebagai basil ijma' sebab ijma memiliki kekuatann hukum yang akan mengikat generasi sesudahnya. Sementara hasil ijtihad jama'i bagaimanapun juga tidak mengikat. $^{24}$

Ibrahim Hosen optimis bahwa apabila kita berhasil menggalakkan ijtihad melalui ijtihad jama'i, maka implikasinya sangat baik dan positif bagi prospek perkembangan hukum Islam pada masa mendatang.

Umat Islam Indonesia akhir-akhir

ini semakin gencar memperl ihat-kan keinginannya untuk menjadikan hukum Islam sebagai suatu sistem kehidupan secara menyeluruh. Tapi sejalan dengan itu timbul pertanyaan. Apakah umat Islam memiliki kemampuan untuk me wujudkan semua itu ? Apakah setelah di-aktualisasikan, hukum Islam mampu menyesuaikan diri dengan tuntutan zaman?

Pertanyaan tersehut tentu kembali kepada umat Islam itu sendiri. Sepanjang mereka memiliki keyakinan dan keperca-yaan yang kuat terhadao hukum Islam, maka sejauh itu pula apa yang mereka dapat wujudkan dalam kehidupannya dari hukum Islam. Dan mengenai pertanyaan kedua, itu j uga tergantung kepada komitmen dan keseriusan umat Islam melakukan ijtihad dalam merespons segala persoalan zaman.

Ibrahim Hosen menggambar kan bahwa di Indonesia masyarakat memiliki dua cara pandang terhadap norma hukum atau aturan yang ada. Di satu sisi, aturan hukum yang dinyatakan bersumber dari Alquran dan Sunnah atau sepanjang dikaitkan dengan produk pemikiran fuqaha (ulama), betapapun mengandung dimensi khilafiah, dipandang memiliki nilai sacral dan bersifat mengikat. Sedangkan di segi lain, norma hukum dalam formulasi perundangundangan (hukum positif) walaupun menjadi bagian organik atau bahkan diserap 
dari dan tidak bertentangan dengan aturan hukum jenis pertama tetap dipandang sebagai aturan yang tidak memiliki nilai sakralitas dan hampa tanggung jawab transendental sehingga dapat dikesampingkan dengan mudah tanpa ada rasa bersalah.

Ibrahim Hosen menawarkan solusi untuk keluar dari dualisme sikap hukum ini supaya semua produk hukum nasional dapat berfungsi secara efektif kepada masyarakat muslim di Indonesia. Dia mengatakan bahwa hukum nasional, baik dilihat dari segi permbuatnya, sumbernya maupun cara penerapannya, tidak dapat kita katakana sebagai hukum yang islami. Akan tetapi, jika dilihat dari segi isinya. Ia dapat dikategorikan islami dengan syarat ia memenuhi kriteria berikut : (a) Ditetapkan Melalui musyawarah (b) Tidak mempersulit umat; (c) Menutup akibat negatif; (d) Mewujudkan kemaslahatan umum; (e) Menciptakan keadilan; (f) Tidak bertentangan dengan jiwa dan semangat nash qath'iy. Bahkan ia tetap dikategorikan islami meskipun materinya itu secara harfiah bertentangan dengan Alquran dan Sunnah dengan catatan dari segi semangat dan jiwanya tidak bertentangan.28 Terhadap hukum nasional semacam inilah umat Islam wajib patuh sebagai realisasi dan aplikasi dari ketaatannya kepada Ulil Amri sebagaimana diperintahkan Allah,

Hai orang-orang beriman, taatlah kepada Allah dan taatlah kepada Rasul dan Ulil Amri dari pada kamu (Q. S. An-Nisa' 59) dengan catatan ia memenuhi enam kriteria di atas.

Dengan demikian, secara teoritis Ibrahim Hosen berhasil keluar dari masalah dualisme hukum Indonesia, antara hukum Islam dan nasional dengan penekanan pada cara hukum diproduksi serta jiwa dan semangat sebuah produk hukum. Dari satu sisi, dia telah berusaha memasangkan pakaian sakralitas terhadap produk hukum nasional dan dari sisi lain dia telah berhasil secara ide mengurangi jarak antara hukum nasional dan hukum Islam.

\section{PENUTUP}

Hukum Islam adalah hukum yang disampaikan Allah melalui wahyu kepada Muhammad Saw. baik dalam bentuk Alquran maupun dalam bentuk Sunnah. Wahyu ini telah terhenti dengan wafatnya Rasulullah sementara dikemudian hari 
banyak masalah yang bermunculan yang hukumnya belum ditegaskan dalam Alquran dan Sunnah. Maka untuk menjawabnya diperlukan ijtihad.

Hukum Islam yang ditetapkan secara tegas dalam Alquran dan Sunnah dikenal dengan istilah Syari'ah, sedangkan yang tidak ditetapkan dengan tegas, yaitu yang dihasilkan dengan ijtihad dikenal dengan istilah fiqih.

Hukum Islam kelompok pertama tidak berlaku ijtihad meskipun masih adskemungkinan untuk difiqihkan. Ia harus diterapkan apa adanya tanpa memperhatikan waktu, tempat dan kondisi serta berlaku sepanjang masa. Sedangkan yang kedua harus tunduk kepada situasi dan kondisi tertentu dan tidak bersifat abadi.

Ijtihad harus dilakukan oleh orang-orang yang memiliki kualifikasi mujtahid. Apabila hal itu tidak dapat dilakukan secara individual, maka iaharus dilakukan secara kolektif. Dalam majelis itulah dipertemukan para ilmuwan dalam berbagai disiplin ilmu yang terkait dengan masalah yang perlu diijtihadkan. Dengan demikian, kelompok ini menutupi syarat-syarat mujtahid yang sulit dipenuhi secara individual.

Hasil ijtihad tidak bersifat mengikat sebab ia bukan ijma'. Sementara ituperaturan pemerintah memiliki kekuatan mengikat yang wajib dipatuhi kaum muslim sepanjang memenuhi keriteria yang enam dan tidak mem-bawa kepada kemaksiatan dan keku-furan nyata. Tapi meskipun demikian, ia tidak dapat digolongkan sebagai fiqih.

Ijtihad kolektif hanya dapat dirasakan manfaat dan perannnya yang lebih besar apabila para ulama yang terlibatdi dalamnya bekerja secara series dalam menjadi relevansi hukum Islam dengan konteks, masyarakat dimana mereka berada. Majelis ijtihad ini pula lah yang diharapkan dapat mengembangkan hukum Islam secara intensif di Indonesia.

\section{CATATAN KAKI :}

1. Ibrahim Hosen, Figih Perbandingan, (Cet. I; Jakarta Yayasan Ihya Ulumuddin, 1971), h. 2.

2. Abdul Aziz Dahlan, Ensiklopedi Hukum Islam, Jil. II (Cet. I; Jakarta : PT. Ichtiar Baru, Van Hoeve 1996), h. 564.

3. Ibid.Ibid., h. 565

4. Ibrahim Hosen, et.al, "Menyongsong Abadke-2 I Dapatkah Hukum Islam Direktualisasikan?" Mimbar Hukum, No. 12 Tim. V, 1994, h. 2-3. 
5. Abdul Aziz Dahlan, op. cit., h. 567.

6. Ibrahim Hosen, et.al, op. cit., h. 4.

7. Ibid.

8. Abdul Aziz Dahlan, loc. cit., h. 567.

9. Ibrahim Hosen, op. cit., h. 5.

10. Thaha jabir Alwaniy, Nazharat Ta'sisiyyah fi Fiqih al-Aqalliyat (Telaah Dasar tentang Fiqih Minoritas), www.iSlarn-on-hne.nci, 21 Oktober 2001.

11. Ibrahim Hosen, op. cit., h. 5.

12. Ibid

13. Ibid

14. Ibid

15. Ibid

16. Ibid, h.6

17. Ibid, h.7

18. Ibid

19. Ibid,h.9

20. Ibid, h.11

21. Ibid

22. Ibid

23. Ibid

24. Ibid

25. Satria Efendi, "Hukum Islam dan Pelaksanaannya di Indonesia" dalam bungs rampai "Figih Indonesia dalam Tantangan", (Cet. I; Surakarta: FIASUMS, 1991), h.34-35.

26. Ibrahim Hosen, "A sas-asas Hukum Perkawinan dalam Kompilasi Hukum Islam" dalambunga rampai "berbagai Pandangan terhadap Kompilasi Hukum Islam ".(Cet. I; Jakarta : Yayasan Al- Hikmah, 1993), h. 49.

27. Ibrahim Hosen, $O p$. cit., h. 13.

28. Ibid., h. 14. 
